\title{
KEDUDUKAN HAK KEPERDATAAN ANAK LUAR KAWIN PERSPEKTIF HUKUM ISLAM
}

\author{
M. Hajir Susanto ${ }^{1}$, Yonika Puspitasari ${ }^{2}$, Muhammad Habibi Miftakhul Marwa ${ }^{3}$ \\ Ilmu Hukum, Fakultas Hukum, Universitas Ahmad Dahlan Yogyakarta \\ Email: hajir.susanto@law.uad.ac.id \\ Email: yonika1400024134@webmail.uad.ac.id \\ Email: habibi.marwa@law.uad.ac.id
}

\begin{abstract}
Constitutionally, every citizen has civil rights that must be guaranteed and protected. Not all children are born lucky. There are children born from legal marriage bonds called legitimate children. Meanwhile, the so-called illegitimate child is a child born not in a legal marriage where the man and woman are still virgins and virgins. The existence of differences in the rights received by legitimate children and illegitimate children is interesting to study using various perspectives, one of which is the perspective of Islamic law. This research is normative research using secondary data sources obtained through literature study. The data obtained were analyzed descriptively using the concept Islamic law approach. The lineage of children in Islamic law is distinguished between children who are not fertilized in a legal marriage but are born in a legal marriage, with children who are fertilized and born outside legal marriage. The position of an illegitimate child according to Islamic law only has a civil relationship with the mother and the mother's family. As for the relationship of a child out of wedlock with his father according to Islamic law, that is, he does not have civil rights in the form of no nasab relationship, does not inherit from each other, and cannot become a marriage guardian.
\end{abstract}

Keywords: Children Out of Wedlock, Civil Rights, Islamic Law.

\begin{abstract}
Abstrak
Secara konstitusional setiap warga negara mempunyai hak keperdataan yang harus dijamin dan dilindungi. Tidak semua anak lahir bernasib baik. Ada anak dilahirkan dari ikatan perkawinan yang sah disebut anak sah. Sementara, disebut anak luar kawin yaitu anak yang lahir tidak dalam ikatan perkawinan yang sah di mana laki-laki dan perempuan yang masih perjaka dan perawan. Adanya perbedaan hak yang diterima anak sah dengan anak luar kawin menarik untuk dikaji menggunakan berbagai perspektif, salah satu perspektif hukum Islam. Penelitian ini merupakan penelitian normatif dengan menggunakan sumber data sekunder yang diperoleh melalui studi pustaka. Data yang diperoleh dianalisis secara deskriptif menggunakan pendekatan konsep hukum Islam. Nasab anak dalam hukum Islam dibedakan antara anak yang dibuahi tidak dalam perkawinan sah namun dilahirkan dalam perkawinan yang sah, dengan anak yang dibuahi dan dilahirkan di luar perkawinan yang sah. Kedudukan anak luar kawin menurut hukum Islam hanya memiliki hubungan keperdataan dengan ibu dan keluarga ibu. Adapun hubungan anak luar kawin dengan bapaknya menurut hukum Islam, yakni tidak memilik hak keperdataan berupa tidak ada hubungan nasab, tidak saling mewarisi, dan tidak dapat menjadi wali nikah.
\end{abstract}

Kata Kunci: Anak Luar Kawin, Hak Keperdataan, Hukum Islam. 


\section{PENDAHULUAN}

Negara hukum memiliki pengaturan tentang Hak Asasi Manusia (HAM) untuk menjamin setiap warga negara. Pasal 28B Undang-Undang Dasar Negara Republik Indonesia Tahun 1945 (disingkat UUD NRI 1945) menyatakan bahwa hak setiap orang untuk membentuk keluarga dan memperoleh keturunan melalui ikatan perkawinan yang sah. Namun, kenyataan di lapangan menunjukkan bahwa ada seorang anak yang terlahir tidak melalui perkawinan yang sah. Kelahirannya membuat masu keluarga karena anak tersebut dihasilkan dari hubungan di luar nikah yang tidak dibenarkan oleh agama dan norma yang berlaku di masyarakat. Anak yang demikian disebut anak luar kawin, yaitu anak yang dilahirkan oleh seorang perempuan, sementara perempuan tersebut tidak dalam ikatan perkawinan yang sah dengan laki-laki yang menyetubuhinya (Manan, 2008: 80).

Anak dalam lingkungan hukum keluarga senantiasa berkaitan dengan persoalan hubungan antara anak dengan orang tuanya dan hubungan anak dengan keluarga. Pada prinsipnya setiap anak berhak mendapatkan hak keperdataan. Anak yang dilahirkan dari hubungan perkawinan yang sah memiliki status dan kedudukan yang sah juga di mata hukum, begitu sebaliknya anak yang lahir dari perkawinan yang tidak sah akan menyandang anak luar kawin. Persoalan mengenai kedudukan anak yang lahir di luar ikatan perkawinan yang tidak sah dalam pandangan hukum keluarga merupakan persoalan yang sensitif, karena yang dibahas adalah sesuatu yang dianggap tidak umum dan menjadi aib bagi keluarga. Namun demikian, hukum harus memberikan respon terhadap problematika yang sedang dihadapi masyarakat sebagai bentuk untuk memberikan kepastian hukum, mengingat anak luar nikah tidak hanya berdampak pada aspek hukum saja tetapi juga persoalan sosial yang dapat menghambat hidup masa depan anak (Mangiri, 
2016: 28).

Pokok persoalan anak luar kawin berada pada hubungan hukum antara anak dengan ayah biologisnya. Sementara hubungan anak dengan ibu tidak menjadi soal, karena hubungan hukum itu timbul dengan sendirinya tanpa diawali dengan perbuatan hukum, kecuali sebagaimana yang diatur dalam Kitab Undang-Undang Hukum Perdata (disingkat KUH Perdata) yang menganut prinsip pengakuan mutlak, yakni ibu kandung (biologis) tidak serta merta menjadi ibu yang memiliki hubungan perdata dengan anaknya tanda perbuatan hukum berupa pengakuan. Pengaturan ini tentu berbeda dengan Undang-Undang Nomor 1 Tahun 1974 tentang Perkawinan (disingkat Undang-Undang Perkawinan) yang menegaskan kalau anak yang lahir demi hukum secara otomatis memiliki hubungan keperdataan dengan ibu dan keluarga ibu tanpa harus melalui lembaga pengakuan (Maulina et al., 2013: 7).

Secara konstitusional setiap anak berhak mendapatkan hak-haknya yang telah dijamin oleh undang-undang dan tidak berhak untuk mendapatkan perlakuan diskriminatif dan negara wajib memberikan perlindungan terhadap setiap anak. Adanya perbedaan hak keperdaan antara anak sah dan anak luar kawin menimbulkan persoalan di masyarakat. Melihat problem yang demikian maka ada sebagian masyarakat yang berupaya ke Mahkamah Konstitusi yakni Aisyah Mochtar untuk mengajukan permohonan uji materiil atas dasar hak konstitusional sebagai warga negara yang dianggap telah terlanggar dengan adanya ketentuan Pasal 2 ayat (2) dan Pasal 43 ayat (1) Undang-Undang Nomor 1 Tahun 1974 tentang Perkawinan karena dianggap bertentangan dengan Undang-Undang Dasar Negara Republik Indonesia 1945 Pasal 28B ayat (1) dan ayat (2) serta Pasal 28D ayat (1). Hingga akhirnya Mahkamah Konstitusi mengabulkan permohonan judicial review dan 
mengeluarkan Putusan Mahkamah Konstitusi Nomor 46/PUU-VIII/2010 tanggal 17 Februari 2012 yang intinya anak yang dilahirkan di luar perkawinan mempunyai hubungan perdata dengan ibu dan keluarga ibu serta dengan laki-laki sebagai ayahnya yang dapat dibuktikan berdasarkan ilmu pengetahuan dan teknologi dan/atau alat bukti lain menurut hukum mempunyai hubungan darah, termasuk hubungan perdata dengan keluarga ayahnya. Berdasarkan latar belakang tersebut, bagaimana kedudukan hak keperdataan anak luar kawin perspektif hukum Islam?

\section{METODE PENELITIAN}

Penelitian ini termasuk jenis penelitian kualitatif berupa penelitian hukum normatif (normative legal research) dengan sumber data sekunder yang diperoleh melalui studi pustaka (literatur research) dari bahan hukum primer, sekunder, dan tersier. Data yang diperoleh kemudian dianalisis secara deskriptif menggunakan pendekatan konsep (conceptual approach) (Dewata \& Achmad, 2010: 186) hukum Islam yang membahas mengenai anak luar nikah.

\section{PEMBAHASAN}

\section{Penentuan Nasab Anak dalam Hukum Islam}

Hubungan kekeluargaan dalam konsep hukum Islam disebut nasab. Menurut Wahbah Zuhaili, nasab adalah sandaran yang kokoh untuk meletakkan suatu hubungan kekeluargaan berdasarkan kesatuan darah (Witanto, 2012: 78). Kajian hukum Islam membedakan anak luar nikah menjadi menjadi dua kategori. Pertama. Anak yang dibuahi tidak dalam perkawinan yang sah, namun dilahirkan dalam perkawinan yang sah. Imam 
Syafii dan Imam Malik, berpendapat anak yang lahir setelah enam bulan dari perkawinan ibu dan bapaknya, maka anak tersebut dapat dinasabkan kepada bapaknya. Namun, jika anak itu dilahirkan sebelum enam bulan maka hanya dapat dinasabkan kepada ibunya saja. Imam Abu Hanifah, berpendapat beda, menurutnya anak luar kawin tetap dinasabkan kepada bapaknya sebagai anak yang sah. Kedua. Anak yang dibuahi dan dilahirkan di luar ikatan perkawinan yang sah. Anak yang demikian ini disebut anak zina dan anak li'an.

Anak dengan kategori anak zina dan anak li'an memiliki akibat hukum berupa: (1) Tidak memiliki hubungan nasab dengan bapaknya, melainkan hanya dengan ibu dan keluarga ibu saja. Dalam hal ini bapak tidak memiliki kewajiban memberikan nafkah kepada anak, namun secara biologis tetap sebagai anaknya. Dapat dikatakan hubungan yang terjadi adalah bukan hubungan hukum tetapi hanya hubungan manusiawi. (2) Tidak saling mewarisi dengan bapaknya, karena hubungan hukumnya hanya dengan ibu. Hal ini dapat dipahami karena salah satu rukun dan syarat untuk dapat saling mewarisi adalah adanya hubungan hukum nasab dengan pewaris. (3) Bapak tidak dapat menjadi wali nikah bagi anak di luar kawin (Witanto, 2012: 79).

Hukum Islam mensyaratkan ada empat hal agar nasab anak dianggap sah. (1) Kehamilan seorang istri bukan hal yang mustahil, maksudnya normal dan wajar untuk hamil. Menurut Imam Abu Hanifah, meskipun suami-istri tidak melakukan hubungan seksual tetapi anak tersebut lahir dari istri yang dinikahi secara sah, maka status anak yang dilahirkan tersebut adalah anak sah. (2) Tenggang waktu kelahiran dengan pelaksanaan perkawinan minimal enam bulan sejak akad perkawinan dilangsungkan. Para ulama sepakat mengenai hal ini, bahwa enam bulan sebagai masa terpendek dari suatu kehamilan. (3) Anak yang lahir terjadi dalam waktu kurang dari masa sepanjang kehamilan. (4) Suami 
tidak ingkar terhadap anak tersebut melalui lembagana yang dinamakan li an. Apabila suami meragukan akan batas minimal antara waktu perkawinan dengan kelahiran, maka suami dapat mengingkari anak yang dikandung istrinya dengan cara li'an. Baik batas minimal tidak terpenuhi dalam hal kehamilan atau bahkan batas maksimal kehamilan terlampaui (Manan, 2008: 79). Seorang suami yang berhasil membuktikan pengingkaran anak yang dilahirkan oleh isterinya, akan berdampak terhadap status anak yang dilahirkan menjadi anak tidak sah dan saat itu juga hubungan keperdataan dengan bapaknya terputus. Berdasarkan Intruksi Presiden Republik Indonesia Nomor 1 Tahun 1991 Tentang Penyebarluasan Kompilasi Hukum Islam (disingkat KHI) Pasal 102 ayat (1) menjelaskan bahwa suami diberikan kesempatan untuk mengajukan gugatan pengingkaran anak yaitu 180 sejak kelahiran anak atau sejak 360 hari sejak putusnya perkawinan.

\section{Kedudukan Anak Luar Kawin dalam Hukum Islam}

Allah Swt. tidak pernah mengelompokkan manusia berdasarkan status kelahirannya, tetapi lebih ditekankan pada aspek ketakwaan orang. Sebagaimana firman Allah Swt.: “...sesungguhnya orang yang paling mulia di sisi Allah adalah yang paling bertakwa kepada Allah.” (Q.S. Al-Hujurat: 13). Islam sebagai agama tidak mengajarkan bahwa dosa seseorang dapat dilimpahkan kepada orang lain. Begitu juga dosa yang dilakukan orang tua tidak dapat diturunkan begitu saja kepada anaknya. Islam sangat tegas terhadap pelaku zina. Bukan berarti anak yang dilahirkan dari perbuatan zina disejajarkan kedudukannya dengan orang tua yang melakukan perbuatan zina.

Pembahasan mengenai status dan kedudukan anak luar nikah dengan orang tua biologis dalam hukum Islam menimbulkan persoalan di kalangan ulama fikih. Para ulama berbeda pendapat mengenai apakah anak perempuan hasil perzinahan itu dapat dinikahi 
atau tidak oleh ayah biologisnya. Hal ini seperti yang ditegaskan dalam KHI bahwa anak luar nikah (perempuan) tidak memiliki hubungan nasab dengan bapaknya. Jika anak tersebut tidak memiliki nasab dengan ayah biologisnya, maka yang bersangkutan akan terbebas dari larangan menikah dengan calon pasangan yang masih memiliki hubungan nasab, kerebat semenda, dan pertalian persusuan.

Imam Malik dan Imam Syafii berpendapat laki-laki (bapak biologis) boleh menikahi anak perempuan, cucu perempuan, saudara perempuan, keponakan perempuan hasil perzinahannya, karena perempuan-perempuan tersebut tidak memiliki nasab dengan bapak biologis. Tentu ini akan menimbulkan perdebatan ketika dihubungkan dengan larangan perkawinan karena masih memiliki pertalian persusuan, sebab susu yang diminum anak akan mengalir menjadi darah dan daging di tubuhnya (Witanto, 2012: 79).

Kenyataan adanya anak yang dilahirkan di luar pernikahan yang sah harus dipahami secara menyeluruh, melihatnya tidak hanya dari perbuatan orang tuanya tetapi juga menyangkut anak yang dilahirkan. Namun, jumhur ulama secara tegas telah menyatakan bahwa anak luar nikah tidak dapat dinasabkan dengan bapak biologisnya. Ketentuan tersebut telah menjadi kesepakatan hukum para ulama. Meskipun demikian, bukan berarti laki-laki yang merupakan bapak biologisnya dapat menelantarkan begitu saja terhadap anak yang diyakini berasal dari benihnya. Masih ada sisi kemanusiaan yang dapat diberikan bapak kepada anak, meski secara hukum syar'i hal itu tidak memiliki nasab. Jadi, secara moral kemanusiaan bapak memiliki kewajiban mencukup kebutuhan anak, karena agama tidak membenarkan penelantaran anak.

\section{Hak Keperdataan Anak Luar Kawin dalam Hukum Islam}

Pengaturan hukum perkawinan bagi Warga Negara Indonesia (WNI) yang 
beragama Islam diatur dalam Kompilasi Hukum Islam BAB II tentang Dasar-Dasar Perkawinan. Dalam Islam perkawinan bukan hanya sekedar akad dan upacara perkawinan, lebih dari itu merupakan bentuk ibadah kepada Allah karena tujuan dari perkawinan menurut Islam salah satunya adalah menghindarkan diri dari perbuatan zina. Pasal 4 Kompilasi Hukum Islam menyatakan "Perkawinan adalah sah, apabila dilakukan menurut hukum Islam sesuai dengan Pasal 2 ayat (1) Undang-Undang Perkawinan”. Pernyataan Pasal 4 KHI menegaskan adanya kesesuaian antara KHI dengan Undang-Undang Perkawinan. Hal ini karena KHI disusun sebagai pelaksanaan praktis yang bertujuan untuk melengkapi Undang-Undang Perkawinan. Undang-Undang Perkawinan sebagai induk dari KHI. Seluruh materi dalam Undang-Undang Perkawinan dipindahkan ke dalam KHI meskipun dengan rumusan yang berbeda (Syarifuddin, 2007: 31). Pasal 5 ayat (1) KHI menegaskan "Agar terjamin ketertiban perkawinan bagi masyarakat Islam setiap perkawinan harus dicatat" dan Pasal 6 ayat (2) "perkawinan yang dilakukan di luar pengawasan Pegawai Pencatat Nikah tidak mempunyai kekuatan hukum". Dengan demikian pencatatan perkawinan ini sangat penting dalam rangka menciptakan kepastian hukum dari suatu perkawinan yang telah dilangsungkan secara agama.

Pengaturan perkawinan tidak hanya dilihat dari hukum agama saja, namun ada peran pemerintah yang mempunyai kepentingan untuk melindungi warga negaranya. Salah satunya yaitu dengan melakukan kewajiban pencatatan perkawinan bagi yang melangsungkan perkawinan yaitu dengan penerbitkan Akta Nikah yang menyatakan telah terjadi perkawinan antara suami istri yang sah menurut agama, sekaligus diakui sah oleh pemerintah. Pasal 99 KHI menyebutkan pengertian anak sah yaitu "Anak yang dilahirkan dalam atau akibat perkawinan yang sah, hasil perbuatan suami istri yang sah diluar rahim 
dan dilahirkan oleh istri tersebut". Dengan menggunakan logika argumentum a contrario terhadap Pasal tersebut, anak luar kawin dapat dipahami sebagai anak yang tidak dilahirkan dalam ikatan perkawinan yang sah.

Akibat hukum dari anak luar kawin menurut hukum Islam yaitu anak tidak memperoleh hubungan nasab, nafkah, hak waris, pemeliharaan (pengasuhan anak), perwalian, melainkan hanya mendapat semua itu dari ibunya. Hubungan perdata timbul dari adanya hubungan nasab. seperti yang telah dijelaskan kesebelumnya bahwa nasab adalah pertalian atau perhubungan yang menentukan asal-usul seorang manusia dalam pertalian darahnya (Witanto, 2012: 84). Tujuan perkawinan dalam Islam salah satunya untuk mendapatkan keturunan perkawinan yang sah, sehingga akan memperoleh nasab yang jelas dari anak yang akan dilahirkan tersebut. Artinya, anak sah mempunyai ayah dan ibu, sedangkan anak yang dilahirkan di luar ikatan perkawinan, status anak hanya mempunyai nasab dengan ibu dan keluarga ibu, sementara ia (anak yang dilahirkan di luar ikatan perkawinan) tidak memiliki nasab dengan bapak atau keluarga bapaknya.

Kedudukan seorang anak yang berstatus sebagai anak yang lahir di luar perkawinan menimbulkan beberapa akibat hukum yang melekat padanya yakni:

Pertama. Hak mengetahui asal usul. Perkawinan dalam Islam memiliki tujuan untuk memiliki keturunan, sehingga anak yang lahir memiliki status sebagai anak sah yang mempunyai seorang ayah dan ibu. Menurut Pasal 103 KHI bahwa asal usul anak dapat diketahui dengan bukti akta kelahiran atau alat bukti lainnya. Apabila akta kelahiran atau alat bukti lainnya tidak ada, maka Pengadilan Agama dapat mengeluarkan penetapan tentang asal usul anak setelah diadakan pemeriksaan secara teliti berdasarkan bukti-bukti yang sah. Berdasarkan ketetapan Pengadilan Agama tersebut, instansi pencatatan kelahiran 
yang ada dalam daerah hukum Pengadilan Agama tersebut mengeluarkan akta kelahiran bagi anak yang bersangkutan.

Anak luar kawin berhak mendapat akta kelahiran sebagai identitas kewarganegaraanya dan mengetahui asal usulnya. Namun, berbeda dengan anak sah di mana dalam akta kelahiran nama ayah dicantumkan di dalamnya, sementara anak luar kawin nama ayah tidak dicantumkan. Hal ini dapat dimengerti karena di hadapan hukum anak tersebut lahir dari perkawinan di luar nikah, tidak catatkan sehingga tidak dapat menunjukkan akta perkawinan sebagai bukti perkawinan orang tuanya.

Kedua. Hak mendapat pemeliharaan dan pendidikan dari orang tua. Pada prinsipnya setiap anak berhak mendapatkan pemeliharaan dan pendidikan. Konstitusi UUD NRI 1945 Pasal 28B menyatakan "Setiap anak berhak atas kelangsungan hidup, tumbuh, dan berkembang serta berhak atas perlindungan dari kekerasan dan diskriminasi." Ketentuan ini dipertegas dalam Pasal 4-18 Undang-Undang Nomor 23 Tahun 2002 tentang Perlindungan Anak, bahwa hak-hak anak di antaranya hak memperoleh pendidikan dan pengajaran. Hak ini sebagai wujud untuk mengembangan potensi intelektual anak (Candra, 2018: 64). Namun, beban memberikan pendidikan dan pengajaran kepada anak luar kawin dibebankan kepada ibu dan keluarga ibunya. Hal ini karena anak luar kawin hanya memiliki hubungan hukum dengan ibu, tidak ada hubungan nasab dengan ayahnya.

Ketiga. Hak nafkah. Anak luar kawin hanya memiliki hubungan nasab dengan ibunya, maka hal yang berhubungan dengan pemberian nafkah hanya ditanggung oleh pihak ibu dan keluarga ibunya. Sesuai Pasal 100 KHI “Anak yang lahir di luar perkawinan hanya mempunyai hubungan nasab dengan ibunya dan keluarga ibunya", sehingga tidak ada kewajiban ayah biologis untuk memberikan nafkah kepada anak tersebut. Meskipun 
dalam kehidupan masyarakat ada beberapa ayah biologis yang memberi nafkah kepada anak luar kawin, namun hal itu hanya bersifat tanggungjawab kemanusiaan bukan tanggungjawab hukum. Sehingga, anak tersebut secara hukum tidak berhak untuk menuntut nafkah dari ayah biologisnya (Susanti, 2013: 4).

Keempat. Hak perwalian. Jika hubungan laki-laki dan perempuan di luar nikah lahir anak perempuan dan setelah dewasa anak tersebut akan menikah, maka ayah biologis tidak berhak atau menikahkan anak tersebut sebagai wali nikah. Pasal 20 KHI menyebutkan bahwa "Yang bertindak sebagai wali nikah ialah seorang laki-laki yang memenuhi syarat hukum Islam yakni muslim, akil, dan baligh”.

Kelima. Hak warisan. Hukum Islam menetapkan bahwa anak menempati garis kewarisan pertama dalam hak menerima warisan dari orang tuanya. Namun, ini tidak berlaku bagi anak luar kawin yang statusnya sebagai anak tidak sah yang hanya memiliki hubungan keperdataan dengan ibu dan keluarga ibunya. Pasal 100 KHI menyatakan "Anak yang lahir di luar perkawinan hanya mempunyai hubungan nasab dengan ibunya dan keluarga ibunya." Pasal 171 huruf c KHI "Ahli waris adalah orang yang pada saat meninggal dunia mempunyai hubungan darah atau hubungan perkawinan dengan pewaris, beragama Islam dan tidak terhalang karena hukum untuk menjadi ahli waris". Pernyataan di atas menegaskan bahwa Pasal $100 \mathrm{KHI}$ mengatur mengenai kedudukan anak luar kawin, sementara Pasal 171 huruf c KHI mengatur mengenai ahli waris yang berhak mendapat hak warisan. Ringkasnya, karena anak luar kawin hanya memiliki nasab dengan ibu dan keluarga ibunya, maka anak luar nikah hanya bisa saling mewarisi dari ibu dan keluarga ibunya, sementara dengan bapak dan keluarga bapaknya tidak bisa saling mewarisi. Anak luar kawin hanya memiliki hubungan nasab dengan ibunya, dalam hal ayah meninggal 
dunia tanpa adanya itshbat nikah (pengakuan/pengesahan perkawinan) antara ayah dan ibu maka anak luar kawin itu tidak mewarisi dari ayahnya. Hal ini dipertegas dalam fatwa MUI dalam putusannya tanggal 31 Oktober 2012 yang menyatakan bahwa anak luar kawin hanyalah berhak atas wasiat wajibah (Sabila, 2017: 103). Status anak di luar kawin (zina) dalam khasanah ilmu fikih menimbulkan persoalan terhadap orang tua biologisnya. Fuqaha sepakat bahwa apabila terjadi zina antara orang tua anak, maka tidak ada hak mewarisi antara anak yang dilahirkan melalui zina dan orang-orang yang lahir dari mani orang tuanya, sebab anak tersebut secara syariah tidak memiliki nasab yang sah dengannya (Witanto, 2012: 87).

\section{SIMPULAN}

Kedudukan anak menurut hukum Islam sebagaimana yang terkandung dalam KHI pada prinsipnya memiliki perspektif yang sama dengan Undang-Undang Perkawinan. Pasal 100 KHI memuat rumusan yang tidak jauh berbeda dengan Pasal 43 ayat (1) UndangUndang Perkawinan, di mana anak luar kawin hanya memiliki hubungan nasab dengan ibu dan keluarga ibunya. Walaupun secara hukum keperdataan Islam anak luar nikah tidak memiliki hubungan nasab dengan bapak biologisnya, bukan berarti bapak biologis secara kemanusiaan tidak memiliki tanggungjawab kepada anak yang dilahirkan hasil dari benihnya. Anak luar nikah perspektif hukum Islam tidak memperoleh pengakuan dari bapak biologis, sehingga tidak berhak mendapatkan hak keperdataan berbentuk hak nasab, hak waris, dan hak wali. Adapun terkait hak nafkah, anak luar kawin berhak memperoleh nafkah dari ayah biologis seperlunya hingga berusia selaku hukuman $t a$ ' zir untuk bapaknya. 


\section{DAFTAR PUSTAKA}

\section{Buku}

Candra, M. (2018). Aspek Hukum Perlindungan Anak di Indonesia: Analisis tentang Perkawinan di Bawah Umur (1st ed.). Prenadamedia Group.

Dewata, M. F. N., \& Achmad, Y. (2010). Dualisme Penelitian Hukum Normatif \& Empiris (I). Pustaka Pelajar.

Manan, A. (2008). Aneka Masalah Hukum Perdata Islam di Indonesia (2nd ed.). Kencana Prenada Media Group.

Syarifuddin, A. (2007). Hukum Perkawinan Islam di Indonesia: Antara Fiqh Munakahat dan Undang-Undang Perkawinan (2nd ed.). Prenada Media.

Witanto, D. Y. (2012). Hukum Keluarga: Hak dan Kedudukan Anak Luar Kawin Pasca Keluarnya Putusan MK Tentang Uji Materiil UU Perkawinan (Pertama). Prestasi Pustaka.

\section{Jurnal}

Mangiri, C. M. (2016). Kedudukan Anak Luar Kawin Menurut Undang-Undang Perkawinan No.1 Tahun 1974 dan Hukum Kanonik. Lex Crimen, V(7), $27-34$.

Maulina, D., Sugijono, \& Susanti, D. O. (2013). Legitime Portie Bagi Anak Luar Kawin Yang Diakui Secara Sah Menurut Kitab Undang-Undang Hukum Perdata. Artikel Ilmiah Hasil Penelitian Mahasiswa Universitas Jember, 1, 1-11.

Sabila, H. M. (2017). Analisis Pasal 100 Komplikasi Hukum Islam tentang Nasab Luar Perkawinan dan implikasinya Terhadap Akta Kelahiran dalam Perspektif Hukum Islam. Skripsi Institut Agama Islam Negeri Walisongo.

Susanti, A. D. (2013). Tinjauan Yuridis Mengenai Kedudukan dan Pembinaan Anak Luar Kawin Dilihay dari Seri Hukum Perdata. Jurnal Ilmu Hukum Opinion, 1(4), 1-9.

\section{Perundang-Undangan:}

Undang-Undang Dasar Negara Republik Indonesia Tahun 1945

Undang-Undang R.I. No. 1 Tahun 1974, Perkawinan, L.N.R.I. Tahun 1974 No. 1

Undang-Undang R.I. No.16 Tahun 2019, Perubahan Atas Undang-Undang Nomor 1 Tahun 1974 tentang Perkawinan, L.N.R.I. Tahun 2019 No. 186

Intruksi Presiden Republik Indonesia Nomor 1 Tahun 1991 Tentang Penyebarluasan Kompilasi Hukum Islam 